\title{
Shakespeare and the Concepts of Fear
}

Robert Appelbaum

\section{(2) OpenEdition \\ Journals}

Electronic version

URL: https://journals.openedition.org/shakespeare/4006

DOI: 10.4000/shakespeare.4006

ISSN: 2271-6424

\section{Publisher}

Société Française Shakespeare

\section{Electronic reference}

Robert Appelbaum, "Shakespeare and the Concepts of Fear", Actes des congrès de la Société française Shakespeare [Online], 36 | 2018, Online since 22 January 2018, connection on 25 August 2021. URL: http://journals.openedition.org/shakespeare/4006 ; DOI: https://doi.org/10.4000/shakespeare.4006

This text was automatically generated on 25 August 2021.

(c) SFS 


\title{
Shakespeare and the Concepts of Fear
}

\author{
Robert Appelbaum
}

1 I say the concepts of fear, not concept, for there are many of them. The word fear itself is polysemantic, and explanations of fear range from the clinical and neural to the philosophical. There are also many related terms, which are commonly used to indicate states of mind or emotions that are not quite "fear" but something a little different, or several things a little bit different, or very much different, as the case may be. Anxiety, terror, horror, panic are among these terms, all of them certainly bearing resemblances to fear but also indicating separate kinds of states of mind. These terms too are polysemantic and can be explained in a large number of different ways.

2 Given this variegated conceptual and terminological field, my purpose here, to adopt an expression of Raymond Carver's, is to ask "What do we talk about when we talk about fear?" And to go one step further, "What do we talk about when we talk about fear in Shakespeare?" There is a gap between the two questions. Our own common discourses of fear and similar phenomena have been affected by conditions unknown and unforeseeable by Shakespeare, ranging from the invention of nuclear weaponry to the development of cognitive science, not to mention the evolution of the English language. Our minds are attuned to fear in many new ways. We may or may not have more to fear today ${ }^{1}$ - after all, if we can fear nuclear war, terrorism, cybercrime, environmental catastrophe and the human immunodeficiency virus, early moderns could fear the Apocalypse. They could fear hell. They could fear hunger and invasion. They could fear military disasters. They could fear the plague and many other diseases for which there was no effective cure. ${ }^{2}$ But whether or not we have more to fear, we have many different objects of fear, and different ways of accounting for it. So a gap of time yawns between then and now. Yet there is also a continuity between the two questions. In this essay I will try to illustrate some of those gaps and continuities, and hopefully clarify what it is, or rather what those many things are, that we talk about when we talk about fear - and especially in Shakespeare. I will then go on to illustrate 
one of the lines of thinking opened up by a consideration of the concepts of fear with reference to Hamlet.

3 I start with a list of words and a few expressions, then. It is not exhaustive or systematic but it is indicative of the wide range of concepts of fear today, and in most cases of the concepts of fear that either appear in Shakespeare, though perhaps with different meanings, or else are absent from a terminological point of view but present phenomenologically.

Fear

Anxiety

Phobia

Paranoia

Obsessive Compulsion

Panic

Dread

Terror

Horror

Awe

"I fear that ..."

"I am afraid that ..."

"I dare not ..."

4 Little by little in what follows I go on to provide applications and examples. There are some surprises ahead. They issue in part from the main premise informing this paper, that the languages and concepts of fear are not systematically coherent. Even though common language, whether now or then, encourages us to think the opposite, they are not systematically coherent in our own time and they weren't in Shakespeare's time either. That represents a challenge to analysis and interpretation. Recently a number of studies of emotions in Shakespeare and his contemporaries have appeared, often focusing on the constructedness of the affective life, with emphases on humoral psychology, theatrical experience, religious doctrine, and the politics of theatre. ${ }^{3}$ But there has been little work on fear, ${ }^{4}$ and little meta-analysis of the terms and concepts involved in the study of any Shakespearean emotions, and therefore of the kinds of assumptions we bring to bear on the study of them. In some ways, I hope to show, we have a relationship to fear which Shakespeare has already anticipated and rejected. In others, we have a conceptual apparatus that can help us understand Shakespearean texts in new ways, and which I do not believe we should reject merely in the name of avoiding the bugbear of anachronism. I am not a presentist, but I nevertheless believe that as long as we respect historical difference we need not avoid and we need not fear insights into Shakespeare that depend on our current preoccupations, vocabularies, and scientific insights.

5 And so first, fear itself, and the diversity of the meanings that can attributed to the root term. As I have said, common language encourages us to think that "fear" is either a single thing or a group of things systematically related to one another. Of the chief reasons is that, in one of its manifestations, "fear" is used as an umbrella term, both for different kinds of experiences that might be characterized as fearful and for experiences which seem similar to fear but go by other terms- anxiety, panic, terror and the like. But umbrella terms are philosophically and hermeneutically risky. The implication is that all other terms, are species of a genus, fear, and that these other 
forms of experience come out of fear, or descend or develop out of fear. But that is seldom how the English language really works. That is seldom, as far as we can tell so far, how the mind works either. ${ }^{5}$ There are psychologists and cognitive scientists who nevertheless refer to "basic emotions" of which "fear" takes pride of place, and other emotions, like anxiety, are gradations. Psychologists may differ in some details, but those who espouse the case for basic emotions usually include (along with fear) disgust, anger, joy, sadness, love, and surprise. ${ }^{6}$ There are no healthy human beings anywhere who do not experience these emotions. They seem to involve activity in the same ostensibly primitive brain region (primitive from an evolutionary point of view), and we share them with many other animals.

6 Yet there is a reductiveness in this reasoning, even when practiced under the rubric of psychoanalysis, and a methodological hastiness as well. ${ }^{7}$ Is "sadness" really at heart one kind of phenomena, and are phenomena like "grief" and "depression" really variants or sub-species? Is a mother sad at the death of a child sad in the same way as a dog left alone at home missing its master? Wittgenstein would probably say that "family resemblances" have been mistaken for essences. Ian Hacking would say that psychology has been mistaken for botany, complex psychological processes for lines of taxonomies based on demonstrable evolutionary descent. ${ }^{8}$ Some psychologists argue strenuously that psychological states should never be mistaken for "natural kinds." Some would also say that cognition has been left out of the picture..$^{10}$ To be afraid is to be aware of something and thus of something apprehended just as to be sad is usually to be sad about something. ${ }^{11}$ Yet others would add that there are many somethings out there. So far as the brain is a network of mappings and associations, there is seldom any one thing apprehended in the mind that amounts to what may seem to be a singular emotion..$^{12}$ To be sure, we can locate neural activity that is triggered in cases of what is often called "fear," located first of all in the amygdala, which is connected to the more extensive limbic system. But even this idea of a location of emotion is subject to doubt, and so is the nature of the amygdala. ${ }^{13}$ And our own language, and Shakespeare's as well, tell us that what we think about when we think about fear is much more complex and diverse than that. Language shows us that fear and related terms are many things, not all of them entirely commensurate with others. We need a lot of different words not only to express nuances, but to indicate specific states and dispositions, whose differences are as important as their similarities.

7 Even the umbrella term is more complicated than at first appears. Consider one of the most famous expressions about fear, Franklin Delano Roosevelt's saying "We have nothing to fear but fear itself." Well, maybe. But how does one fear fear? The saying actually echoes a comment by Montaigne: "The thing in the world I am most afraid of is fear." ("C'est de quoi j'ai le plus de peur que la peur.") ${ }^{14}$ But again, how does one do that, and fear fear? It would seem possible only if two different meanings of fear are being played with here, one being apprehensiveness about what may occur in the future, the other a crippling worry in response to a present danger. The only thing we have to apprehensive about is a future worry that will paralyze us, preventing us from taking appropriate action. Fear here is two things rather than one. Consider next the entry in the Oxford English Dictionary on fear. It says that fear is primarily "the emotion of pain or uneasiness caused by the sense of impending danger, or by the prospect of some possible evil". But who thinks of fear as pain or uneasiness? When I am frightened by something, I am not in pain, and I am not merely uneasy. And is there not a difference between responding to an impending danger and a future prospect of evil? 
Words are hard to define, of course. But the Oxford English Dictionary then goes on to refer to the use of the word familiarly as an umbrella term, suggesting also that is used not to be so: Fear is "now the general term for all degrees of the emotion," it says; but "in early use applied to its more violent extremes, now denoted by alarm, terror, fright, dread." ${ }^{15}$ We will actually not find much substantiation for that last qualification in Shakespeare, who in fact uses the term to denote anything from a rather mild worry about what may be in the future to alarm concerning the present. But the upshot is clear. In English - I won't speak for any other languages here - fear seems to be one thing, but it is actually many. If fear is commonly used as an umbrella term, moreover, it is used that way only at the price of considerable ambiguity and confusion. The term fear - in early modern English the now obsolete pleonasm "dread and fear" was common, as in The Rape of Lucrece's "Till sable night, mother of dread and fear" ${ }^{16}$ encourages us to think there are many kinds of fear, not all, even few of them being fearful in the same way. It is very hard, however, perhaps impossible, to say exactly what makes them aligned.

Psychologists, to be sure, especially those inclined to think of "fear" as a primary or base emotion, and who in addition find explanatory power for the emotions in evolution, commonly think of fear as an instinct-based physiological and/or neurological event that provokes the subject into action: flight, fight, or paralysis. Faced with danger, I run away, I confront my danger, or I freeze. Danger is key to fear in this sense. And the emotion - the Oxford English Dictionary allows for this in its definition (3d) - is that feeling or apprehension that something perilous is about to happen. I believe this is the most common understanding of the word today. That shocking feeling that I have to get away, or take action, or that I need to do one or the other and am unable to do either, that feeling that as it were assaults me, takes hold of me, given a possibly perilous future - that is fear, in the first instance. ${ }^{17}$

But there are other complications. I can experience fear when I see someone else in danger: for example, a child wandering too close to the edge of a platform in Metro station. I experience fear for the child but in me. The flight, fight, or paralysis options work much differently as a result, and they may be compared in this respect to the options I experience emotionally when I see something fearful in a drama or a film. I experience fear for the character in peril; but the emotional options are moot, since, unlike the child in the Metro station, there is nothing I can possibly do for him or her. And then there is the fear experienced which is not even fear for another. I am afraid that two cars on the road ahead of me are going to crash into one another. And it is not because I have an empathetic intimation of the people in the cars. I am afraid simply that a disaster is going to happen, beyond my control. "Why do they run away?" asks Bottom, entering as an ass in front of his friends. "This is a knavery to make me afeard" (3.1.100). The friends are afraid of a man with the head of a beast. Bottom thinks he is being tricked into being frightened by an unknown impending danger, signalled by people running away, about which he will be able to do nothing. But he will not be afraid. So there is fear of an impending unknown evil, and there is possible a resistance to the very concept of fear. (In other words, one can articulate the abstraction, fear, without experiencing it.)

10 In addition to these fears about known and unknown dangers, for oneself and for others, there are also less objective fears: fears of strangeness, fears of disorientation, fears of being abandoned and alone: children especially are prone to these fears, most 
popularly in fears of the dark, of "sable night," but of course adults can suffer from them too. ${ }^{18}$ All of these varieties of feeling, it needs emphasizing, can be found in Shakespeare, and perhaps other varieties not yet named. Consider another case from $A$ Midsummer Night's Dream. When Hermia wakes up from a menacing dream in the middle of the forest, and her lover Lysander is nowhere to be seen, she cries out, "I swoon almost with fear" (2.2.160). She is afraid for herself; she is afraid for Lysander. She is afraid in her current condition, she is afraid because of what she saw in her dream, a snake eating her heart, and she is afraid for the future. She is afraid, for the most part, not because a present danger has alarmed her, but rather because of dangers remembered and dangers imagined. She is afraid of the strangeness of the forest and its darkness and the apprehension that she is alone. She is afraid that Lysander will betray her. To her credit, she does not allow herself to be paralyzed. She goes in search of Lysander, worrying that if she does not find him she will die. In a sense, Hermia conquers her fears - an important idea in Shakespeare, as we have already begun to see.

11 So in general and certainly in the experience of Shakespearean characters, there are many kinds of fear, many objects, many imaginary objects, and many absences feared as if they were objects. There are even several different kinds of fear that can be experienced together. But let us take it for granted for the time being that what we most commonly mean by fear in the first instance is this impulse to fight, flee, or freeze, keeping in mind that we have already located at least six alternatives, the "prospect of a future evil," the fear for another, the fear for a situation, the fear for a fictional character, the fear of strangeness and the fear of being alone. Even so, then come all those companion terms.

12 Anxiety is next on the list, and rightly so. ${ }^{19}$ Since the nineteenth century, anxiety has been a key term for understanding not only psychology but the human condition in general. It seems to be especially pertinent today. A recent search of the MLA International Bibliography shows over 4000 recent entries where a key word is anxiety; and there are many scholarly articles and books which attribute anxiety to a condition of or in Shakespearean drama. But why? I will get back to that. But first it needs to be noted that the word is never used by Shakespeare, although it was not unknown in the sixteenth century. Death "is a remedy moost present for all euyls, and the chefest expeller of al anxieties," wrote William Hugh in 1549 - anxiety here apparently being used, much like fear, as an umbrella term (Oxford English Dictionary: 1b). If we attribute anxiety to a condition of or in Shakespearean drama or poetry we attribute it to phenomena that Shakespeare does not name as such. Our own preoccupations are in play. But that does not mean that the attribution is incorrect. Anxieties of various kinds - "national anxiety," "genealogical anxiety," "cultural anxiety," "the anxiety of deception," "ethical anxiety," "sexual anxiety", "racial anxiety" - have proliferated in early modern studies, and even on the level of individual characters in early modern drama a condition of what we call anxiety may sometimes be found - perhaps Hamlet, above all. Since W.H. Auden's poem by the name, from decade to decade intellectuals have been inclined to think that we live in an "age of anxiety." But if that is the case, when we are moved or disturbed by Shakespearean phenomena we may be inclined to attribute to something familiar from this our own age rather than his.

13 Is there is a base or first instance of meaning to the word anxiety? If so, it is probably this: fear without a secure object. If fear is usually fear of something, anxiety is fear of 
nothing - not of something here or there or of something gone missing, but precisely of nothing. Hobbes described anxiety as a fear for the future, but in the sense that the future was not something that could be known. ${ }^{20}$ It was not a thing. When Kierkegaard took up the topic, this psychological condition also became ontological, epistemological, ethical and ultimately theological. Kierkegaard defines anxiety as the condition of sin, of the fallenness that all of us share - or more positively, in a definition that resounds through all existentialist thought, "freedom's actuality as the possibility of possibility." ${ }^{21}$ We are all anxious because we have to be: the objects and stimuli of our life are not secure, and we apprehend them insecurely, although at the same time we know that the insecurity of our objects and stimuli are also indicators of our freedom, or rather of our ability to be free, and that ability makes us leery; it makes us want to recline into the comfort of dependency, of conventional thinking, of ideology and myth. Confronted with what we do not know, we respond with anxiety; or else, we sense that we are really free and know what we ought to do, but mainly in the sense that we only see the possibility of our being free - not the thing, which doesn't exist - and we are left with emptiness. If only we could be dependent! If only we weren't aware of the possibility of being free! For Heidegger anxiety is the state of mind that reacts with alarm at "Being-in-the-world as such." ${ }^{22}$ And so again the problem of freedom comes into play: "Anxiety makes manifest in Dasein its Being towards its own inmost potentiality-for-Being - that is, its Being-free for the freedom of choosing itself and taking hold of itself." ${ }^{23}$

But there is clinical anxiety too, a mental or emotional disorder, which is not to be underestimated: it afflicts hundreds of millions, forty million in the United States alone. ${ }^{24}$ Above all there is what the DSM-5 calls "generalized anxiety disorder," a prolonged condition when no threats are perceived, when no danger, imaginary or real, lies in one's way; but when one is all the same afraid..$^{25}$ Sometimes the word "hyper-arousal" is added. The anxious person is stimulated by more than a situation warrants. ${ }^{26}$ Instead of being normatively wary, the subject is pathologically vigilant, or, as we say, unnerved. It is my impression that the use of the word "anxiety" in Shakespeare studies focuses on this later idea of hyper-arousal, combining it with ideas, rooted in psychoanalysis, of repression and displacement. ${ }^{27}$ The named phenomenon thus serves as both an acute symptom and a hidden cause, often generalized as a social rather than a merely personal ill. That is not what modern clinical psychology would recommend, for in most modern practice anxiety is an observable and describable syndrome, not something hidden away, and not something driving us we know not where. And it is personal rather than social. We are in anxiety if we suffer from the disorder; the cure comes in individually finding our way out. Yet in some cases, notwithstanding modern clinical psychology, some literary analysis focussed on causal and symptomatic anxieties may be correct. In Freud's later work, the anxiety concerning something unknown, and unknown because it is repressed, expresses itself in neurotic behaviour, for example hysteria and phobia. Repression comes first; anxiety follows; and then the symptom follows after. But the symptom may well be not, say, sexual paralysis or a phobic episode, but an anxiety attack. ${ }^{28}$ That is, the condition may express itself as a condition, the hidden anxiety being also a visible knot of hyper-aroused feelings and ideas. For anxiety is not just a condition; it is also an affect. Lacan might agree, though Lacan insists that anxiety is not fear without an object; it is rather a field of significant experience, where something has been at once lost and sought for: the signifier. Anxiety is a tear, a cut, a rift in a chain of 
signification; and it is the condition that makes it possible, even necessary, to confront the world with uneasy uncertainty. Anxiety is a sign of helplessness in the face of the Real. It is even "a signal of the real." ${ }^{29}$

15 Next on the list, phobia, already mentioned above, is another word not present in Shakespeare, and not available to him either. It only entered our vocabulary in the 1950s. Yet the phenomenon was not unknown in the early modern period. There may be some examples in Shakespeare: Ford's fear of cuckoldry in The Merry Wives of Windsor may be a case in point, as may be Lucrece's fear of the dark. Certainly there are several examples in the comedies of Ben Jonson, most notably Morose in Epicoene; or The Silent Woman, who is phobic about noise. Robert Burton mentions a few; for example, fear of water, hydrophobia..$^{30}$ Phobia is fear attached to very specific objects or situations, which have no objective facticity. A phobic individual experiences something like "fear" when no real danger is at hand, but he or she becomes alarmed whenever a certain thing or situation is perceived or anticipated which might be dangerous if comes into direct contact with either the thing or the situation. A phobia can be terrifying. It can lead to panic, vertigo, revulsion. And when it is developed with response to imaginary objects, to mere fantasies, it becomes what we call paranoia, the next term on our list. Paranoia is another term not available to Shakespeare, but a case can be made that some of the obsessive fearfulness of some of his characters can be denoted by the term. It has been argued, for example, that Macbeth comes to suffer paranoia. ${ }^{31}$ The problem with saying that Macbeth is paranoid, however, is that many of his fears turn out to be right. In Macbeth Shakespeare dramatizes a tragic version of an old joke: "Just because you're paranoid doesn't mean they aren't after you." Interestingly, both phobia and paranoia appear to be univocal terms. It may be argued in any given case whether phobia or paranoia are present; but common language and clinical language both are pretty clear about what they refer to. (A complication arises with terms like "homophobia," where fear is mixed with hatred.)

So, fear, anxiety, phobia and paranoia. Next on the list is obsessive compulsion, a fear which is not so much felt or consciously recognised as it is acted out: here the object and stimulus are present, but they present something that is not really there. The obsessive compulsive is afraid because of a compulsion to be afraid, and luckily, unlike the person suffering from generalized anxiety, he or she has a remedy at hand, an obsessive ritual. Shakespeare's Lady Macbeth is sometimes said to suffer from this syndrome ${ }^{32}$ but in Lady Macbeth's case the ritual is ineffective, and the end result is suicide. She compulsively washes her hands, but without any effect. Apparently this is not to be unexpected; it has been shown that OCD sufferers have a much higher rate of suicide and suicide attempts than the average population..$^{33}$

17 Panic comes next. If fear is the apprehension of danger which may lead to an impulse of flight, fight, or paralysis, panic can occur either with or without a genuine apprehension of danger. It is an experience of fear or anxiety that causes the individual (or sometimes whole crowds) to spin out of control, to act wildly, hysterically, irrationally, destructively, the body breaking down under the weight of its own fright, the mind struggling to think what it is thinking. An impulse neither to fly, fight, or remain still, panic is a vertiginous, trembling, or raging condition, which may then lead either to nervous paralysis or an irrational acting out. Panic attacks, a common complaint today, are similar to what in early modern England were sometimes called furies or fits, although in the furies panic turns to anger, whereas in panic attacks 
anger is unavailable as an outlet. Shakespeare does not use the term. But it is possible that what Othello suffers when, as stage directions put it, he "falls into a trance" is a panic attack (4.1.41). He falls into a trance because he fears the implications of his suspicions about Desdemona: his own absurdity, his own violence, his own freedom to do evil. It is also possible to name what Macbeth feels when he sees Banquo's ghost a panic attack. Lady Macbeth calls what he experiences a "fit," a "momentary" fit although again, his panic attack may be a symptom of a general condition of paranoia (Macbeth, 3.4.54). Montaigne, in his essay on fear, refers to the wild behaviour of troops in the face of danger as a "terreur panique." ${ }^{34}$ In Florio's translation of Montaigne, the same expression is translated as "panic terror." 35

Then there is dread, not a clinical term today and not much used anymore except to indicate an intense fear which is mixed with aversion, provoking avoidance. The word in Shakespeare is usually tamer than it is today, though it is frequently related not just to aversion and avoidance but also to awe and submission, especially with regard to sovereign authority. Powerful officials are dread lords, meaning I think dreaded lords, but dreaded for the right reason; they are powerful; they command paramilitary retinues and legal privileges; and they can do you harm. It is probably pertinent that Hamlet talks about "the dread of something after death" and not "the fear" of it. That "dread" seems to indicate intensity, aversion and awe all at once, with the hint that what is to be feared in the afterlife is something sovereign and not be defied. One dreads what cannot be avoided, because it is the law, but one wants to avoid it all the same, since it is, well, dreadful.

There are companion terms that we use today that were not used by Shakespeare: worry, solicitude, inhibition. I have not put them on the list, but I remark that these terms are part our languages of fear; and if we say that a Shakespearean character or poetic speaker is worried, solicitous, or inhibited we are not necessarily wrong. Many times when a Shakespearean character says, "I fear that ..." or "I doubt that ...", we would use the expression "I worry that ...", though that now common sense of the word "worry" only comes to us from the nineteenth century. If ever Claudius and Gertrude are actually worried for the health of Hamlet, and keen to do something about it, they are in our terms not only worried but "solicitous": a word available to Shakespeare but not common in his period, and never used by him. As for inhibition, the psychological sense of the word familiar to us today of an inner restraint, related to a conscious or unconscious fear of what would happen if one were not restrained, was not available to Shakespeare. We should be wary of that. But I find convincing a description of Romeo, where it is said that by the end of the play he is "no longer the withdrawn inhibited character of Act One." ${ }^{36}$

And again there are the twin concepts of terror and horror. They are not clinical terms, but they are much with us today. They are so much with us today, since the French Terror, the invention of horror fiction, the coming of horror movies, the terrorist movements of the nineteenth and twentieth century, and all the publicity that terrorism today both seeks and finds, that they can only with caution be used to describe a Shakespearean phenomenon. However, Shakespeare himself uses the words, and with some consistency. As for terror, most dictionaries define it as being merely a heightened degree of fear (regarding it as an umbrella term); but terror is traditionally associated, in many European languages, with a fear that makes one tremble. Adriana Cavarero, who has written at length on the subject, adds that this trembling is a motor 
force, sending the body into motion in reaction to a perceived danger. A terrified person is apt to flee. As for horror, Cavarera goes on to say, if terror is about trembling, horror is about bristling; it is about the hair on the back of your head sticking out. More important to the meaning, though, even for Cavarero, is the association of horror with aversion or disgust. Cavarero contrasts horror with terror by adding that if terror makes one flee, the disgust of horror leads to paralysis. ${ }^{37}$ The distinction is interesting, but it would seem to be another example of someone trying to pin down polysemantic terms in the name of scientific clarity, even though the polysemanticism is part of what is important about the terms. If I am terrified, I may well find myself paralyzed. If I am horrified, I may well flee the scene.

21 An important quality of both terror and horror (which Cavarero does not account for) is that they can be used to designate either the quality of thing or person that causes them, or else the condition of being terrified or horrified. When a headline today says, "Terror in the streets of ...," it is following this tradition, for there is both something terrible in the streets and people who are terrified. Especially with the word terror, Shakespeare prefers to use it for the cause rather than the effect, often applied to powerful magnates. "What a terror he had been to France", says Talbot about Salisbury (1 Henry VI, 2.2.17). "[We] lent him our terror, dressed him with our love" says the Duke about Claudius (Measure for Measure, 1.1.19). ${ }^{38}$ Shakespeare does sometimes use the word to designate the state of being terrified, to be sure (he never uses either "terrified" or "terrorized", though he does use the cognate "terrible"): Says Lucrece to Tarquin:

The guilt being great, the fear doth still exceed;

And extreme fear can neither fight nor fly,

But coward-like with trembling terror die (The Rape of Lucrece, 225-231).

But perhaps even in this last example, Shakespeare seems to link the emotion of terror to objective conditions which are found not only in the body of the terrorized, like trembling, but in the world itself. Natural and even supernatural enormities are sometimes associated by the playwright with terror: "Methinks King Richard and I should meet / With no less terror than the elements", says Bolingbroke (Richard II, 3.3.53-54). Cassius refers to "The unaccustomed terror of this night," meaning both the storm and the "apparent prodigies" people report having seen and heard (Julius Caesar 2.1.199). Macbeth, using the cognate, says that he has "terrible dreams" and he tells Lady Macbeth about murders "too terrible" to be spoken about (3.2.20). Although it may be acceptable to say today that terror is an "extreme fear," and even Shakespeare has equated the two in the example from Lucrece, Shakespeare is more apt to frame terror less as a fearfulness than as a perception of a disturbance in the order of things, a disturbance which cannot be fought against, and probably cannot be fled from either - which is part of what it "terrible" about it. ${ }^{39}$ Or else, he uses it to refer to magnates like Henry V bespeaking their own lawful terror

As for horror, it is a rare word in Shakespeare, but when it appears it communicates powerfully. When Macduff finds the body of Duncan, recently and secretly murdered by Macbeth, he cries out "O horror, horror, horror! Tongue nor heart / Cannot conceive nor name thee" (Macbeth, 2.3.59). The cognate term "horrible" is used similarly, designating something that is at once frightful and taboo, almost inconceivable, not to mention disgusting. The ghost of Banquo for example is a "horrible sight" (Macbeth 4.2.138). And then of course comes Hamlet's ghost, reporting on life in Purgatory: "O horrible! O horrible! Most horrible!" (Hamlet Q2, 1.5.80) 
Last comes awe, a concept already included in the idea of dread, but a concept with a range of references all its own. In brief, awe is in the first instance a combination of fear and reverence. It was common in Shakespeare's England to speak of the awe of God - and the problem with such awe, if it is applied to responses to any object but God, is that it demands that we love the thing that overwhelms us, that reduces us and makes us timid. Threatens Henry V, "France being ours, we'll bend it to our awe" (Henry V, 1.2.224). But note again, like terror and horror, awe can refer either to a subjective state or to the object that causes it. The awe of God or King is at once part of what it means to be God or a King and part of what it means to experience what God or a King are - to me. But the concept of awe is precisely what Cassius contests in Julius Caesar, speaking to Brutus:

[...] for my single self,

I had as lief not be as live to be

In awe of such a thing as I myself.

I was born free as Caesar; so were you (1.2.95-99).

The idea is that one cannot be in awe of someone to whom one is equal, especially if one knows exactly what one is.

As already noted, I have also added to the list some expressions, "I fear that," I am afraid that...", (or, in Shakespeare, "I am afeard that"), and "I dare not...". It is important to note these expressions because they indicate that fear is not just a substantive, but also a part of the grammar of emotions. And sometimes, with these expressions, the concept of fear merges with the concept of being sorry. That is, the expression indicates a concession to the one who is spoken too. Says the computer Hal, in 2001: A Space Odyssey, when he is commanded to open a hatch, "I'm sorry Dave, I'm afraid I can't do that". ${ }^{40}$ In addition, the expressions "fear" or one of its cognates may function as a marker of a mood, what might be called the negative subjunctive. Says Brutus in Julius Caesar, "I do fear, the people / Choose Caesar for their king" (1.2.82-83). Says Cassius a little later, "I fear our purpose is discovered." (3.1.17).

And then there is the similar locution, to dare, or dare not. Says Alexis to Antony, in Antony and Cleopatra: "Good majesty, Herod of Jewry dare not look upon you / But when you are well pleased" (3.3.3). Says Scarus, a servant of Cleopatra, "the augurers / Say they know not, they cannot tell; look grimly, / And dare not speak their knowledge" (4.13.4-6). These expressions mark a kind of hesitation, mixed with uncertainty on the one hand and dread of a bad outcome on the other. They avoid committal, and they incline toward politeness - that is, toward saying not what one means, but rather saying a little bit less than one means for the sake of propriety, congeniality and safety. And then there is a locution that indicates that one should be ready for something that one may fear: wariness, as in to be wary, or more plainly, sometimes, beware. "Be wary then;" Laertes says to Ophelia, "best safety lies in fear" (Hamlet Q2, 1.3.43). I hardly need mention the wariness that Caesar is supposed to feel about the Ides of March. Wariness, it would seem, is a self-defensive state of mind.

So there are many kinds of fear, many uses of the word fear and its companion terms, and many situations in which fear or its companion terms are useful indicators both of objective conditions and subjective responses. That is so now, and that was so in Shakespeare's day. A problem comes when we think we are using a univocal term. Another problem comes when we think that in referring to an affect like fear, we are referring to only an affect, only a subjective condition. Such an idea indicates a bias at least as old as William James, if not Descartes, where the affective life is psychological 
life, and psychological life is rooted in the physiology of the body. Such an idea also correlates with a bias as old as Plato but that is especially pertinent today, in this age of neoliberalism, where phenomena like emotions are understood to be subjective states subject to management and therapeutic intervention. I do not, as I have indicated, object to using terms from today to describe phenomena in Shakespeare. But I think we need to be cautious in how we use them. We need to be especially cautious about thinking that just because we have landed on a medical term and its analysis that Shakespeare may have been familiar with, we have an infallible key to Shakespearean discourse.

Agreed: there are corporeal and clinical subjective conditions with which Shakespeare was familiar and which helped him express human emotion, even taught him how to express it. But what many accounts are leaving out is the prodigiousness of Shakespeare's simulations of the human. Shakespeare can well regard the fears of his dramatis personae as being in some sense sick, or at least expressive of a character flaw. But that is only the beginning. He may also have them (and his speakers in poetry) distinguish between fears of present danger and fears for a danger to come. He may show characters and poetic subjects suffering from cowardice in the face of minor evils and anxiety in the face of they know not what. He may show them terrified or horrified, or awestruck by the power of magnates or the supernatural. He can show them obsessive or in panic. He can show them engaging in a grammar of fear partly out of respect for their interlocutors and partly out of respect for their own uncertainties.

But that is not all. For Shakespeare also consistently shows the varieties of fears as being bound with social, political and moral life, with concepts of justice, virtue, inequality, spiritual dignity and the historical moment. He thus also shows them (as we have already seen in the case of "terror") being tied to objective conditions, or conditions that are taken to be objective, which bear upon historical circumstances as well as what might be taken as human nature.

To illustrate that point, and provide a preliminary conclusion, let me make a few remarks, as I have promised, about one of Shakespeare's great assassins, Hamlet. I have already noted a few varieties of the concept of fear in the Hamlet play. And I have hinted, too, that though the concept of anxiety goes unnamed in all of Shakespeare's work, it is plausible to claim that Hamlet himself labours under a condition of anxiety. The idea is not new. Kierkegaard made the claim, saying that Hamlet suffered from religious doubt and all that entailed, including an inescapable sense of original sin, and of bearing the responsibility for a crime he did not commit. ${ }^{41}$ The clinically minded may also have reason to think that the character of Hamlet expresses a simulation of general anxiety, which is commonly coupled (we now know from a clinical point of view) with what Hamlet himself tells us he suffers from, melancholy - what today we call depression - as well as a sense of indeterminate guilt. Are we wrong to think that way? Again, simulations of these conditions are what is at stake, not the real thing. But why couldn't Shakespeare have simulated them, even if he sometimes lacked a clinical category for naming them? In fact, in Hamlet the playwright calls attention to the puzzling namelessness for Hamlet's situation. And he does so by underscoring the nonanxious forms of fear that Hamlet does not suffer. For again, the very idea of fears of various kinds are connected in Shakespeare's work with ostensibly objective conditions.

31 Consider part of a speech by Hamlet, in act two: ${ }^{42}$ 
Am I a coward?

Who calls me villain? breaks my pate across?

Plucks off my beard, and blows it in my face?

Tweaks me by the nose? gives me the lie i' the throat, carve

As deep as to the lungs? Who does me this?

Ha? (Hamlet Q2, 2.2.506-511)

Am I a coward? The answer is no. Because if someone defied me directly I would not be afraid. I would act. So I am not afraid. It is not fear that holds me back, or not the fear that gets expressed through paralysis or flight in the face of impending danger. But what then? What empirically do I suffer from? Consider what Hamlet compares himself to in this speech - a rogue, a peasant slave, an ass and a prostitute. In such comparisons Hamlet ventures the idea that the resistance to fear - the quality called courage - is not only subjective and personal, but also objective, socially and morally and maybe even ontologically. By hesitating to act, Hamlet says, I am acting like a rogue, a peasant slave, and so on. This quality in Hamlet which today we might call anxiety is compared by Hamlet himself to the kind of timidity that belongs objectively either to someone on the margins of society, a rogue, or to someone at the very bottom of society, a peasant and a slave, not to mention an ass or a whore. To be at the top of society, in this view, to be a prince, means first of all not to be afraid.

The emphasis continues in the fourth act, where Hamlet discusses cowardice.

Now, whether it be

Bestial oblivion, or some craven scruple

of thinking too precisely on the event,

A thought which, quartered, hath but one part wisdom

And ever three parts coward [...] (Hamlet Q2, 4.4.38-42).

"Bestial oblivion" - in other words not thinking like a rational human being. To be timid is to be irrational, or at least, not rational enough to realise that there is more to life than eating and sleeping: that life is made for the achievement of honour, first of all. In this case we find Hamlet subscribing to what is technically called a deontological ethic, and also sometimes an ethic of the virtues. And then there is the problem of "craven scruple" - in other words, thinking too much, hiding behind too much rationality. That too leads to a kind of fear - the fear that leads to paralysis. Coleridge, it will be recalled, saw this as the "overbalance of the imaginative power" in relation to reason. "Thinking too precisely on an event"- Camillo, in The Winter's Tale, makes just the same sort of observation. ${ }^{43}$ In these situations it may be pertinent to observe that "thinking" turns into fantasizing, although the fantasy itself is made out of rational considerations.

So we see that being afraid, for Hamlet, in the sense of being unable to act, in the sense of responding to danger with ignoble paralysis, is associated with being socially marginal, mandatorily submissive, irrational, or overly precise. Or else, it is associated with something that goes unnamed, which is not fear. So again our word for Hamlet's condition might well be anxiety, and this anxiety may even be exasperated by Hamlet's not having a word (or an explanation) for it. ${ }^{44}$ To have a diagnosis can be reassuring: "I know what's wrong with me!" Anxiety of some sort in any case may be the general status of Hamlet's mind throughout the play, and there are many examples of specific addresses to the problem. Hyper-arousal, for instance, may be observed in his confrontations with Ophelia and Gertrude. And then there are reflective accounts, as when, in response to Horatio, Hamlet being about to enter his fencing match with Laertes, Hamlet says: "But thou wouldst not think how ill all's here about my heart." 
Remember, this is after Hamlet has also said that he is not afraid about the match. He thinks he is going to win, but nevertheless "all's here" is "ill." challenge the medical regime I referred to, and to strains in modern cognitive science as well. In the societies of Hamlet, the kind of fear that physicians and cognitive scientists warn us against is the least of our worries. In the world of Hamlet fear is embedded in the subject not only as an emotional response to danger, but also, along with its opposite, courage, in the subject's constitution as a moral, political and social being. The fear of present danger is, among many other of shakespeare's virtuous aristocrats, a thing of no account. It is deplorable. "Cowards die many times before their deaths;" says Julius Caesar. "The valiant never taste of death but once" (2.2.32-33). But the fear of future danger, of dangers not completely understood, or not entirely believed in, and possibly imaginary to boot, the fear of the consequences of actions we have not yet undertaken, along with the fear of the consequences that might come if we do not act, especially perhaps if we find that what inhibits us is an intangible and inexcusable awe, based on a failure to appreciate our own dignity - this is one the great fears (or anxieties or obsessions) among shakespeare's armed male elite. Of course, only some of Shakespeare's characters belong to that class.

The field for research lies before us. To what the research will lead I dare not say. But I end with a simple plea. Be wary of what you are saying. And don't let the cognitive scientists dictate what to talk about when you talk about fear in Shakespeare. 


\section{NOTES}

1. For a breezy account of modern fears and anxieties, see Joanna Burke, Fear: A Cultural History, London, Virago, 2005.

2. Some of these fears and others besides are addressed in William Naphy and Penny Roberts, eds, Fear in Early Modern Society, Manchester, Manchester University Press, 1997.

3. Gail Kern Paster, Humoring the Body: Emotion and the Shakespearean Stage, Chicago, University of Chicago Press, 2004; Gail K. Paster, Katherine A. Rowe, and Mary Floyd-Wilson, eds, Reading the Early Modern Passions: Essays in the Cultural History of Emotion, Philadelphia, University of Pennsylvania Press, 2004; Richard Meek, ed. Shakespeare and the Culture of Emotion, Shakespeare 8.3, 2012, Special Issue; Brian Cummings and Freya Sierhuis, eds, Passions and Subjectivity in Early Modern Culture, Farnham, Ashgate, 2013; Katharine A. Craik and Tanya Pollard, eds, Shakespearean Sensations: Experiencing Literature in Early Modern England, Cambridge, Cambridge University Press, 2013; Laurie Johnson, John Sutton, and Evelyn Tribble, eds, Embodied Cognition and Shakespeare's Theatre: The Early Modern Body-Mind, London, Routledge, 2014; Bridget Escolme, Emotional Excess on the Shakespearean Stage: Passion's Slaves, London, Bloomsbury, 2014; R.S. White, K. O'Loughlin, and Mark Houlahan, eds, Shakespeare and Emotions: Inheritances, Enactments, Legacies, Basingstoke, Palgrave Macmillan, 2015; José Manuel González, "Emotion in Cervantes and Shakespeare", Neophilologus 99.4, 2015, 523-538; Steven Mullaney, The Reformation of Emotions in the Age of Shakespeare, Chicago, University of Chicago Press, 2015; Ronda Arab, Michelle Dowd, Adam Zucker, and Phyllis Racklin, eds, Historical Affects and the Early Modern Theater, New York, Routledge, 2015.

4. A notable exception is Allison P. Hopgood, "Feeling Fear in Macbeth," in Shakespearean Sensations, Craik and Pollard, eds, op. cit., 29-47. Hopgood's analysis depends, however, on the assumption that "fear" is a univocal term, and, in Shakespeare's day, entirely pathological. Moreover, it assumes that the "fear" playgoers experience is the same thing as what the characters on stage experience. I will give evidence that all three assumptions are wrong.

5. See for example, Antonio Damasio, The Feeling of What Happens: Body, Emotion and the Making of Consciousness, New York, Vintage 2000. The idea of what constitutes the mind/brain/body is of course still very controversial, and Damasio is only one among contending authorities.

6. For example, Jaak Panksepp The Archaeology of Mind: Neuroevolutionary Origins of Human Emotions, New York, Norton, 2012. Summaries of the various models of basic emotion theory, along with models that contradict it, written by some of the main scientists involved, can be found in James A. Russell, Erika L. Rosenberg and Marc D. Lewis, eds, Basic Emotion Theory, in Emotion Review 3.4 (2011), 363-463.

7. See the discussion in the introduction to Paster, Rowe, Floyd-Wilson, eds, op. cit.

8. Ian Hacking, "Lost in the Forest", London Review of Books, 35.15, 8 August, 2013, 7-8.

9. Lisa Feldman Barrett, “Are Emotions Natural Kinds?", Perspectives on Psychological Science, 1.1 (2006) 25-58; and Kristen A Lindquist, Erika H. Siegel, Karen S. Quigley, and Lisa Feldman Barrett, "The hundred-year emotion war: Are emotions natural kinds or psychological constructions? Comment on Lench, Flores, and Bench (2011)", Psychological Bulletin, 139.1 (2013), 255-263.

10. Philosopher Robert C. Solomon has probably been the most articulate champion of the role of cognition in emotional experience. See Robert C. Solomon, The Passions: Emotions and the Meaning of Life, Indianapolis, Hackett, 1993, and Solomon, Not Passion's Slave: Emotions and Choice, Oxford, Oxford University Press, 2013. The debate has been a central item in the journal Cognition and Emotion since its inception in 1987.

11. The case of the melancholy Antonio in The Merchant of Venice, Antonio's clinical depression, may be an exception that proves the rule. See Drew Daniel, "'Let me have judgment, and the Jew 
his will': Melancholy Epistemology and Masochistic Fantasy in The Merchant of Venice", Shakespeare Quarterly, 61.2 (2010), 206-234, where the object of sadness is phantasmatic, but therefore nonetheless an object.

12. For an interesting application of the polysemantic point of view, see Colin McGinn, The Meaning of Disgust, Oxford, Oxford University Press, 2011.

13. See Lisa Feldman Barrett, How Emotions Are Made: The Secret Life of the Brain, New York, Macmillan, 2017; and Luiz Pessoa, "Emotion and Cognition and the Amygdala: From 'what is it?' to 'what's to be done?' Neuropsychologia, 48.12 (2010), 3416-3429. The authors of "Measures of emotion: A review" write that "although there has been some progress in understanding the neural correlates of fear, disgust, and potentially sadness, the discrete-emotions perspective has yet to produce strong, replicable findings" (Iris B. Mauss and Michael D. Robinson, "Measures of Emotion: A Review", Cognition and Emotion, 23.2 [2009], 209-237).

14. Michel de Montaigne, "Of Fear", in Essays, trans. John Florio, Renascence Editions (University of Oregon), http://www.luminarium.org/renascence-editions/montaigne/; chapter 17, n.p. Michel de Montaigne, "De la peur," Short Edition, http://short-edition.com/fr/classique/michel-demontaigne/de-la-peur, n.p. Last accessed 30 August 2017.

15. Oxford English Dictionary online, s.v. "fear".

16. The Rape of Lucrece, line 117. All selections from Shakespeare's works, with the exception of Hamlet, are taken from the Norton Shakespeare, Second Edition, ed. Stephen Greenblatt et alii, New York, Norton, 2008. Quotes from Hamlet are from the Second Quarto Edition, Hamlet (The Arden Shakespeare, Third Series), ed. Ann Thompson and Neil Taylor, London, Bloomsbury, 2005. They will be cited in the text.

17. Sartre has an especially acute account of the paralysis that can afflict someone in danger, referring to it as "passive fear": "I see a ferocious beast coming towards me: my legs give away under me, my heart beats more feebly, I turn pale, fall down and faint away. No conduct would seem adapted to danger than this, which leaves me defenceless. And nevertheless it is a behaviour of escape; the fainting away is a refuge." Jean-Paul Sartre, Sketch for a Theory of the Emotions, trans. Philip Mairet, London, Routledge, 1962, p. 42. Emphasis in the original.

18. "Fear of the night" had objective causes, Darren Oldridge reminds us, in an age before artificial lighting and a common belief in the devil and evil spirits, who were held to thrive in the dark. Oldridge, "Something for the Night", in Staging the Superstitions in Early Modern Europe, ed. Verena Thiele and Andrew D. McCarthy, Surrey, Ashgate, 2013, xiii-xxiii. Probably the most pertinent early modern text is Thomas Nashe, The Terrors of the Night, or, A Discourse of Apparitions, London, 1594, STC 258:11.

19. For historical background, see Allan V. Horwitz, Anxiety: A Short History, Baltimore, Johns Hopkins University Press, 2013.

20. William W. Sokoloff, "Politics and Anxiety in Thomas Hobbes's Leviathan", Theory and Event 5.1 (2001), n.p.

21. Søren Kierkegaard, The Concept of Anxiety, trans. Reidar Thomte and Albert B. Anderson, Princeton, Princeton University Press, 1980, p.42.

22. Martin Heidegger, Being and Time, trans. John Macquarrie and Edward Robinson, San Francisco, Harper and Row, 1962, p. 230.

23. Ibid., p. 232.

24. Gerald Litwak, "Preface," in Anxiety, Special Issue, ed. Gerald Litwak, Vitamins and Hormones, 103 (2017), p. xv.

25. American Psychiatric Association, Diagnostic and Statistical Manual of Mental Disorders, Fifth Edition (DSM-5), Arlington, VA, American Psychiatric Publishing, 2013. Here and throughout, when I refer to a clinical condition, I have checked it against the Manual. 
26. See Steven Taylor, Dean McKay, Jonathan S. Abramowitz and Gordon J.G. Asmundson, Current Perspectives on the Anxiety Disorders: Implications for DSM-V and Beyond, New York, Springer Publishing, 2009).

27. To give just one of the many possible examples, an excellent essay by Edward A. Snow, "Sexual Anxiety and the Male Order of Things in Othello", English Literary Renaissance, 10.3 (1980), 384-412. The essay abounds with references to "repression," "false consciousness," and "méconnaissance" as well as to Othello's and Iago's excesses of fear about their own sexualities.

28. Sigmund Freud, Complete Psychological Works, Volume 20, trans. James Strachey, London, Hogarth Press, 1959, p. 142.

29. Jacques Lacan, Anxiety: The Seminar of Jacques Lacan, Book X, ed. Jacques-Alain Miller, trans. A.R. Price, Cambridge, Polity Press, 2014.

30. Robert Burton, Anatomy of Melancholy, ed. Holbrook Jackson, New York, New York Review Books, 2001, Part One, Mem. 1, Subs.4, p.141-142.

31. Rick Bowers, "Macbeth and Death: Paranoia and Primogeniture", The Upstart Crow 10 (1990), 55-68; Seth Clark, “'Confusion Now Hath Made His Masterpiece': (Re)Considering the Maddening of Macbeth", Journal of the Wooden 013 (2013), 34-45.

32. See, for example, Wray Herbert, "Damned Spot: Guilt, Scrubbing, and More Guilt" https:// www.psychologicalscience.org/news/were-only-human/damned-spot-guilt-scrubbing-andmore-guilt.html (accessed 2 April 2017).

33. P. Kamath, R.C. Reddy, and T. Kandavel, "Suicidal Behavior in Obsessive-Compulsive Disorder", Journal of Clinical Psychiatry, 68.11 (2007), 1741-1750. Subsequent studies have confirmed this finding, although not always with the same percentages of incidence.

34. Michel de Montaigne, Essais, Livre I, http://www.bribes.org/trismegiste/es1ch17.htm (accessed 30 August 2017); Hopgood, op .cit., also cites this example.

35. Montaigne's Essays, trans. John Florio, op. cit., http://www.luminarium.org/renascenceeditions/montaigne/1xvii.htm (accessed 30 August 2017).

36. Marvin Bennett Krims, The Mind According to Shakespeare: Psychoanalysis in the Bard's Writing, Santa Barbara CA, Praeger, 2006, p. 85

37. Adriana Cavarero, Horrorism: Naming Contemporary Violence, trans. William McCuaig, New York, Columbia University Press, 2011, p. 4-8.

38. There is an interesting use of "terror" in just this way in Bacon: "The King was once in mind to have sent down Flammock and the blacksmith to have been executed in Cornwall, for the more terror" (Francis Bacon, Bacon's History of the Reign of King Henry VII, ed. Joseph Rawson Lumby, Cambridge, Cambridge University Press, 1885, p.156).

39. Robert Burton echoes this duality, or even circularity, in the authorities he cites on "terrors and affrights": "Tully distinguishes these terrors which arise from the apprehension of some terrible object heard or seen, from other fears"; "This terror is most usually caused, as Plutarch will have 'from some imminent danger, when a terrible object is at hand"' (Anatomy of Melancholy, op. cit., p. 335-336).

40. See Lillian Lee, “'I'm sorry Dave, I'm afraid I can't do that': Linguistics, Statistics, and Natural Language Processing circa 2001," Cornell University, http://www.cs.cornell.edu/home/llee/ papers/cstb.pdf (accessed 30 August 2017).

41. James E. Ruoff, "Kierkegaard and Shakespeare", Comparative Literature, 20.4 (1968), 343-354.

42. For a similar analysis to what follows, focusing on Richard III, see Sandra Bonnetto, "Coward Conscience and Bad Conscience in Shakespeare and Nietzsche," Philosophy and Literature, 30 (2006), 512-527. Lacan's analysis of Hamlet also includes an argument of this kind, emphasizing that Hamlet is not afraid of Claudius. See Jacques Lacan, "Desire and the Interpretation of Desire in Hamlet", ed. Jacques-Alain Miller, trans. James Hulbert, Yale French Studies, 55/56 (1977), 11-52.

43. He says that it is "a fear / Which oft infects the wisest" (1.2.263-264). 
44. In his essay on Hamlet, cited above, Lacan never mentions "anxiety", but he does insist that Hamlet is neurotic, an "obsessional neurotic."

\section{ABSTRACTS}

Fear and its companion terms like anxiety, terror, and panic are not systematically related. Our attempts to conceptualize fear and related phenomena are often hampered by assumptions that there is a system of natural kinds in the emotions, when at best there are only what Wittgenstein called family resemblances. There is no one reliable system now and there was no reliable system in Shakespeare's period. This essay examines a variety of terms used to account for phenomena like fear in Shakespeare, as well as the variety of concepts behind the terms. It highlights the hermeneutic challenges posed by fear's polysemanticity, and by the copiousness with which Shakespeare explores all the concepts.

Lorsque l'on pense à la peur, on ne mobilise pas toujours les mots de sens voisin comme anxiété, terreur et panique. Si l'on essaie de conceptualiser la peur et les phénomènes proches, on est souvent gêné par le présupposé qu'il existe un système de types naturels parmi les émotions, alors qu'il y a tout au plus ce que Wittgenstein appelle "un air de famille». Il n'existe pas de système fiable de nos jours, et il n'en existait pas non plus du temps de Shakespeare. Cette contribution étudie un éventail de termes que l'on utilise pour rendre compte de phénomènes tels que la peur chez Shakespeare, ainsi que les différents concepts correspondant à ces termes. Elle met en lumière les défis herméneutiques que posent d'une part le caractère polysémique de la peur, et de l'autre la richesse de l'exploration shakespearienne de tous ces concepts.

\section{INDEX}

Mots-clés: anxiété, Hamlet, neuroscience, peur, polysémie, psychologie clinique

Keywords: anxiety, clinical psychology, fear, Hamlet, neuroscience, polysemanticity

\section{AUTHOR}

\section{ROBERT APPELBAUM}

Uppsala University 